\title{
Factors affecting the application of management accounting in Vietnamese enterprises
}

\author{
Thi Tu Oanh Le ${ }^{a^{*}}$, Thi Ngoc Bui ${ }^{a}$, Thi Thu Phong Tran ${ }^{b}$ and Quoc Hung Nguyen ${ }^{a}$
}

\begin{tabular}{l}
${ }^{a}$ University of Labour and Social Affai \\
${ }^{b}$ Hanoi Open University, Vietnam \\
\hline C H R O N I C L E \\
\hline Article history: \\
Received August 28, 2019 \\
Received in revised format \\
September 28, 2019 \\
Accepted October 222019 \\
Available online \\
October 22 2019 \\
\hline Keywords: \\
Factors \\
Management accounting \\
Management accounting \\
application \\
Vietnam enterprises
\end{tabular}

\section{Introduction}

Rapid changes in global business environment have driven enterprises to transform towards sustainability by focusing on cost efficiency. Many studies have confirmed the benefits of management accounting in improving business sustainability. However, most studies focus on business enterprises since they play an important role in the economic growth in both developing and developed countries (Mitchell \& Reid, 2000). Globally, the number of business enterprises accounts for $99 \%$ of the total organizations. In Vietnam, enterprises account for $97.3 \%$ of the total number of organizations and contribute to $54 \%$ of the Gross Domestic Product (GDP), and create $87 \%$ of jobs for workers. In other words, enterprises play a vital role in economic development in most countries. Therefore, business enterprises have received substantial attention from researchers worldwide. In the globalization context, enterprises are facing many challenges related to sustainable development, technological progress, fierce market competition, changes in management and limitations of capital funding (Nandan, 2010; Ahmad, 2012; Messner, 2016). According to Senftlechner and Hiebl (2015), in order for enterprises to survive and maintain their sustainable development, both financial and non-financial * Corresponding author E-mail address: oanhletu@gmail.com (T.T.O. Le)

\begin{abstract}
A B S T R A C T
Vis paper aims to investigate factors affecting the application of management accounting in sending questionnaires to 120 companies in the manufacturing, trading and service sectors in Vietnam. 6 factors were selected to measure the application of management accounting in enterprises through correlation and regression analysis. The results showed that 5 out of 6
factors positively associated with the level of management accounting application; including firm size, organizational culture, organizational structure, technology and human resources operations. In particular, corporate culture has the highest impact and opinion of managers has the lowest impact on management accounting application. Business environment has a
negative impact on management accounting application in enterprises. Based on the research results, suggestions and recommendations are proposed for enterprises regarding application of management accounting. The research provided an overview of management accounting
application and its benefits to enterprises. Whereby, it helps managers have a better understanding of management accounting and future directions for application. Moreover, the research results will be useful for managers to identify factors influencing their management accounting practices and improve the current management process applied in organizations.
\end{abstract}

C 2020 by the authors; license Growing Science, Canada. 
information should be taken into consideration. As a result, management accounting is considered an effective management tool to support managers in performing management functions because it combines and emphasizes both financial and non-financial information in the decision making process of managers. In addition, management accounting provides various tools, techniques, and internal information for budgeting, executive planning, performance evaluation and decision making. Management accounting practices are not standardized due to a wide variety of business models in the market as well as various application in each enterprise. In Vietnam, although management accounting has been taught in universities since 1995, it has been applied in most Vietnamese enterprises nowadays. However, application of management accounting in Vietnamese enterprises remains at a relatively low level and low effectiveness (Anh, 2016; Hung, 2016). The fact is that enterprises encounter many problems in management accounting application and mainly apply traditional management techniques. Furthermore, the application of management accounting in Vietnamese enterprises is influenced by many factors inside and outside the organizations, which may increase or decrease the feasibility of management accounting application in Vietnamese enterprises. Therefore, it is essential to identify and quantify the impact of each factor on the application of management accounting in Vietnamese enterprises. The research objectives include:

- Identifying factors affecting management accounting application in Vietnamese enterprises;

- Evaluating the degree of impact of each factor on management accounting application;

- Proposing solutions to improve effectiveness of management accounting application in Vietnamese enterprises.

\section{Literature review}

\subsection{Review of international research on factors affecting management accounting application}

Kordlouie and Hosseinpour (2018) conducted a study on 340 enterprises in Iran in which data was collected through questionnaires and analyzed by structural equations. The management accounting techniques applied includes activity-based costing, activity-based budgeting, industry analysis, shareholder value analysis, product life cycle analysis and competitor analysis. The main influential factors include organizational characteristics (including size, competitive strategy and management decentralization), business potential (including customer power, advanced technology and market competition), operational technology (including the complexity of processing systems, advanced manufacturing technology and total quality management). Fasesin (2015) examined factors affecting management accounting in enterprises in Nigeria. The study showed that traditional management accounting techniques were widely applied in furniture manufacturing, food and beverage industry. The main techniques of management accounting applied in companies in Nigeria include controlling information through the use of current accounting data, comparing with data in the past, calculating financial indicators, business analysis and responsibility accounting. Moreover, contemporary management accounting techniques are also applied in listed companies. Particularly, techniques applied by these companies include controlling the planning process and forecasting inventory, customers, market shares, product life cycle. To investigate factors affecting management accounting application, the author applied the research model of Kosaiyakanont (2011). The results showed that in both types of management accounting methods (traditional and contemporary method), the influential factors include managers, finance and company structure with the similar level of impact. Armitage and Webb (2013) conducted a study on application of management accounting in Canadian companies and found that enterprises use budgeting and variance analysis mainly for the planning purposes, and do not focus on controlling function. Strategic management accounting tools such as quality costing, target costing and just in time, activity-based costing or balanced scorecard are not applied. The success of management accounting application in these companies depends on the qualifications of accountants as well as knowledge and experiences of the managers. The study also pointed out other influential factors such as financial capacity, company's investment, market fluctuations and competitors, firm 
size. In particular, firm size has the highest impact (0.345), competitive market has the lowest and negative impact (-0.125) on management accounting application. Michael et al. (2013), Abdel (2008), Abdel (2004) examined the actual management accounting practices in manufacturing companies in the UK. Abdel and Luther (2006) conducted a study on management accounting practices in the food and beverage industry in the UK. The results indicated that management accounting application focuses on controlling information rather than supporting decision making. The research proved that the application of contemporary management accounting depends heavily on internal factors including managers' perspectives, accounting qualifications and financial capacity. External factors affect management accounting application include legal environment, competition, risks, and technological changes. Afirah (2018) carried out a study on management accounting application in 110 enterprises in the East Coast of Malaysia. The study proved that 3 factors affecting management accounting application include organizational characteristics, business potential and operational technology. Since management accounting application in Malaysia is organizational-specific, contingency theory was applied in this study. The research showed that small and medium-sized enterprises adopt the first 2 of the 4 stages of management accounting application based on framework of Nishimura (2003). In addition, the regression results showed that only operational technology has a positive impact on the management accounting application ( $\mathrm{p}$-value $=0.005$ ). The other two variables, namely, organizational characteristics and business potential, had no significantly influence on the management accounting application. These findings are inconsistent with the results of studies on large companies in Malaysia. Ahmad (2012) investigated factors affecting management accounting application of Malaysian enterprises and proved that influential factors include enterprise size, intensity of market competition; participation of the owners in management accounting application and advanced manufacturing technology. Particularly, participation of the owners in management accounting application has the highest impact while advanced technology has the lowest impact. In addition, the research confirmed advantages of management accounting in enhancing management effectiveness and efficiency, increasing profits by reducing wastes and using of resources efficiently. Erserim (2012) conducted research on the impact of internal and external factors on management accounting practices in manufacturing companies in Turkey. Internal factors include firm size, organizational culture and management. The study concluded that firm size has the highest impact on management accounting practices and when a company expands its size (reflected by the number of employees), it requires a more rigorous management through decentralization to achieve optimal efficiency. The research results of Erserim was later applied and developed by Hiebl et al. (2013). The Hiebl's study examined external factors including investment environment, legal environment, cultural environment, social environment, and integration tendencies of countries. In which, investment environment has the highest impact on the process of application, contents and techniques of management accounting

Kosaiyakanont (2011) examined the relationship between perspectives and needs of business owners regarding management accounting application in the North of Thailand. The study showed that the greater the awareness of business owners on the importance and benefits of management accounting, the higher the management accounting needs. Besides, there is a difference in awareness (knowledge) about the importance and benefits of management accounting application between small enterprises and medium-sized enterprises. Particularly, medium-sized enterprises have greater awareness of the importance and benefits of management accounting as well as have higher management accounting needs compared small enterprises. Nandan (2010) studied the management accounting needs in enterprises. The study proved that management accounting information is very important for managers, especially in the management of resources and making decisions on resource allocation. Commonly used techniques include cost-volume-profit analysis, relevant information analysis, decisions making under constraints. Furthermore, knowledge and experiences of managers and qualifications of accountants have the highest impact on management accounting application. Abdel and Luther (2008) conducted a study on management accounting practices in 658 food and beverage companies in the UK. Influential factors examined in the study include perceived environmental uncertainty, organizational structure, firm size, complexity of processing system, advanced manufacturing 
technology, total quality management, just in time system, corporate strategy, customer power, perishability level of products. The research results proved that:

- There is a positive relationship between the level of perceived environmental uncertainty and the level of sophistication of management accounting practices.

- There is a positive relationship between customer power and the level of sophistication of management accounting practices applied by enterprises. The reason is that when customers have higher power, companies have to improve their controlling function and decision making process to satisfy diverse customer needs;

- There is a positive relationship between the level of decentralization and the level of sophistication of management accounting practices;

- There is a positive relationship between enterprise size and the level of sophistication of management accounting practices;

- Companies applying Advanced Manufacturing Technology (AMT), Total Quality Management (TQM), Just in Time (JIT) system are more likely to adopt higher level of sophistication of management accounting practices compared to companies which do not apply AMT, TQM, JIT.

Hyvönen (2007) conducted a research on the management accounting application in manufacturing enterprises and provided empirical evidence on the wider extent of adoption of management accounting practices as well as the perceived benefits from the application and potential development in the future. The results proved that amount of capital, labor and market, cultural background and management habits, advanced manufacturing technology, advanced machinery and equipment were determinants of a success of management accounting application. Chenhall (2007) adopted contingency theory and pointed out that the factors affecting management accounting practices in enterprises include organizational characteristics (including size, competitive strategy and decentralization); business potential (including customer power, technological advancement and market competition); operational technology (including the complexity of processing systems, advanced manufacturing technology and total quality management). This theory supports the idea that there is no universally appropriate accounting system applied equally to all organizations in all circumstances (Otley, 1980). Xydias-Lobo et al. (2004) summarized empirical studies conducted in Australia, the UK and The US and identified the role of environmental factors and organizational factors. Specifically, environmental factors consist of globalization of markets, advances in information and manufacturing technology, increased competition. Organizational factors include core competencies, relationships with customers and suppliers, downsizing, outsourcing, flatter organizational structures, team working. Lavia et al. (2015), Laitinen (2003), Collis (2002) provided factors affecting changes in management accounting practices including motivators (market competition, enterprise structure, production technology), catalysts (financial inefficiency, a decline in market share, organizational changes), facilitators (accounting staff, level of autonomy, accounting requirements). In particular, changes in business environment and technology are considered a key factor affecting the changes of management accounting and strategic structure of enterprises. In contrast, enterprise structure and strategy are linked with changes in management accounting in the same context. Shields (1997) examined American enterprises and found that potential factors leading to changes of management accounting include competition, technology, enterprise structure and strategy. These factors have different impact on changes of management accounting.

Amat et al. (1994) revealed a positive relationship between market competition on the use of management accounting in small and medium-sized enterprises in Spain. The study indicated that when intensity of competition in the market increases, there is also an increase in the use of management accounting. The reason is that competition indirectly puts pressures on the enterprises to acquire more information including both financial and non-financial information to ensure that they remain competitive. Since all mentioned studies were conducted in the different study settings (in terms of geographical region or industry), the findings might vary, however, it is consistent with the 
conception acknowledged by Messner (2016) who stated that the industry plays a vital role in management accounting application in enterprises.

\subsection{Review of studies on management accounting application in Vietnam}

Yen (2017) carried out research on management accounting application on 90 enterprises in Binh Dinh province. The results showed that management accounting application was influenced by three factors: (i) perceived benefits of management accounting; (ii) qualifications of accounting staff; (iii) size of enterprise. These factors were positively related to the success of management accounting application. Anh (2016) examined more than 220 enterprises to understand the impact of management accounting application on corporate performance in the transition economy in Vietnam. The study pointed out that both decentralization and competition had positive impacts on the use of contemporary management accounting techniques, but they had no impact on the use of traditional management accounting techniques. In addition, the study provided that management accounting practices contributed to improving the business performance. Hung (2016) conducted a survey on 186 enterprises and examined 7 factors affecting management accounting application in Vietnamese enterprises; namely enterprise size, cost of management accounting application, organizational culture, qualifications of accountants, corporate strategy, ownership structure, market competition, owner's perspective. These factors explained $34.8 \%$ of the impact on management accounting application in Vietnamese enterprises. The most influential factors are owner's perspective (19.16\%), firm Size (18.67\%) and corporate strategy $(18.19 \%)$. In summary, although each study was conducted in a different context, and in diverse conditions of each country, management accounting practices are influenced by common factors including firm size (capital, number of employees, market, turnover), business environment (intensity of market competition, external environment, politics and laws), organizational culture (organizational design, development strategy, participation of the owners, regulations, working processes, organizational objectives), technology (advanced production technology, modern machinery and equipment), Experiences and knowledge of managers. Besides, some specific factors are examined in previous studies including financial capacity, requirement from outside, number of customers and partners, globalization and integration, market share, changes (regarding organization, human resources, technology). These studies applied qualitative and quantitative methods to investigate factors influencing management accounting practices, however, they did not show the level of application as well as management accounting techniques used in these enterprises. In addition, there has been not much research on factors affecting management accounting application in Vietnamese enterprises which applied a reliable quantitative method. Therefore, this study is conducted to fulfill the above research gaps and provide empirical evidence on the matter.

\section{Methodology}

\subsection{Measurement scales}

The preliminary scales were established based on the research objectives and scales of previous studies. Specifically, measurement scales were established based on prior research of Kordlouie and Hosseinpour (2018), Afirah (2018), Afirah (2017), Hung (2017), Lavia et al. (2015), Ahmad (2012), Abdel \& Luther (2008), Chenhall (2007), Xydias-Lobo et al. (2004), Laitinen (2003) and Shields (1997). Each previous study was analyzed in relation with specific characteristics of culture, society and people of each country which are compared with characteristics of Vietnamese enterprises, sociopolitical system, people and the level of economic development. It is concluded that the majority of Vietnamese enterprises are small and medium-sized enterprises, with low management qualifications, fierce competition of domestic market, developing stock market, the main type of enterprise is Limited Liability Company. Based on that, six factors examined in this study are explained as follows:

Enterprise size: This is an important factor affecting the structure and controlling of enterprises. Based on studies of Kordlouie and Hosseinpour (2018), Afirah (2018), Hung (2017), Armitage and Webb (2013), Michael et al. (2013); Ahmad (2012); Chenhall (2007), Hutaibat (2005), Kader and Luther 
(2008) enterprise size is measured by: the amount of capital, the number of employees, annual turnover, the number of products, market share. According to prior studies, the larger the size of an enterprise, the higher the level of sophistication of management accounting practices. The reasons are explained as follows:

- The more diverse the business sector, the more specialized the management functions. Therefore, sophisticated management accounting techniques are required to perform management functions

- Large enterprises with strong financial capacity and sufficient infrastructure can facilitate management accounting application.

- The larger the size of enterprise, the higher the level of complexity of costing system and budgeting system.

External environment: This is a significant factor which is examined in many studies such as research of Afirah (2018), Armitage and Webb (2013), Michael et al. (2013); Ahmad (2012); Abdel and Luther (2008); Chenhall (2007); Xydias-Lobo et al. (2004); Laitinen (2003); Shields (1997); Mia and Clare (1999). The external environment is examined in the following aspects. Firstly, legal environment includes legal sources which have direct impacts on the enterprises' interests such as the regulations on tax, finance, banking, exchange rates, currencies, interest rates, accounting. Secondly, competitive environment consists of domestic and foreign competitors, competitive price, market, distribution channels and product quality. The competitive market has created chaos, pressure, risks and instability for enterprises. Therefore, enterprises operating in a competitive environment do not have much time to focus on developing the management accounting system. Thirdly, technological environment includes the development of information technology, production technology and management technology. In addition, socio-cultural environment includes globalization, nature, society and perspective. Analysis of environmental factors is displayed as follows:

- The more severe and diverse the environment, the more challenging it is for enterprises to develop management accounting system. The reason is that accounting system, production system, and control system of enterprises are required to be more dynamic, and prompt to ensure more effective control.

- When the external environment is uncertain and unstable, management accounting needs to provide flexible budgeting so that managers can anticipate potential risks and make appropriate decisions to ensure optimal financial control.

- When the external environment is uncertain, management accounting should be more flexible and focus on external subjects which results in the development of strategic management accounting and sustainability management accounting except traditional management accounting.

Opinion of managers: This factor directly affects the management accounting application in enterprises according to Afirah (2018), Hung (2017), Fasesin (2015), Michael et al. (2013); Armitage and Webb (2013), Ahmad (2012), Laitinen (2003), Shields (1997) and Ahmad (2012). Opinion of managers is examined in three aspects: Firstly, awareness of management accounting is reflected by the understanding of basic techniques and contents of management accounting such as budgeting, establishing standards, understanding basic management accounting reports, identifying criteria and methods to evaluate performance, ability to use management accounting information to make business decisions. Secondly, appreciation of benefits of management accounting is the result of fully understanding of management accounting. Thirdly, willingness of managers to apply management accounting in their organizations also affects the management accounting practices. Furthermore, accounting knowledge and experiences also play a vital role in management accounting application. It can be assumed that:

- Managers with high awareness and appreciation of the role of management accounting are more likely to apply management accounting in their organizations .

- Prior studies proved that there is a positive relationship between qualifications of accounting staff and knowledge/understanding of management accounting and management accounting application in enterprises. 
Organizational structure: This factor is examined in studies of Fasesin (2015), Abdel and Luther (2008), Chenhall (2007) and Laitinen (2003). An enterprise is considered to have a strict organizational structure when it is divided into separate units/departments. Each small unit has its specific functions, rights and obligations. Each unit must perform its own performance evaluation according to the general requirements of the enterprise. Therefore, each unit will have its own reporting system to send to managers and related departments. Following assumptions are made:

- An enterprise with higher degree of decentralization tends to apply more sophisticated management accounting techniques to provide relevant information for managers in the process of planning, controlling and making decisions.

- In an organization with a complex structure, complex management accounting practices are required to ensure effective planning, controlling and evaluation. Furthermore, management accounting practices in each department/unit are more diverse and complicated.

Technology: Ahmad (2012), Abdel and Luther (2008), Chenhall (2007), Xydias-Lobo et al. (2004), Laitinen (2003), Shields (1997) assessed technology in the following aspects manufacturing process, sales process, human resources management process, automation of accounting system with the support of advanced machinery, artificial intelligence. In addition, enterprises may apply Advanced Manufacturing Technology (AMT), Total Quality Management (TQM), or Just in Time (JIT) system with the support of robots to improve efficiency and effectiveness of production process.

- If the production process applies highly advanced technology, the control system becomes more standardized, the role of management control might diminish. Specifically, in enterprises with hightech production processes, the inputs as well as production standards and production processes are established and fixed. Therefore, budgeting of enterprises applying advanced technology become simpler since there are fewer fluctuating factors which need to be forecasted compared to budgeting of other enterprises.

- When companies apply technology with a high degree of automation which can perform uncertain tasks/ objectives, management accounting practices become more flexible and unstandardized. Accordingly, management accounting can provide more relevant, and useful information promptly. In other words, advanced technology can provide information for strategic management with provision of non-financial information.

Organizational culture: Regarding impact of organizational culture on management accounting application, Hung (2017), Erserim (2012), Chenhall (2007), Xydias-Lobo et al. (2004), Laitinen (2003) examined organizational culture in following aspects: organizational regulations on finance, operations, working, behaviors, reward, penalty, and management which might affect management accounting application.

- The culture of each region and each unit directly influence the design and use of management accounting practices.

- Units with modern culture are more likely to apply management accounting with diverse techniques.

\subsection{Dependent variable: Management accounting application in enterprises}

Armitage and Webb (2013), Michael et al. (2012), Ahmad (2012), Kosaiyakanont (2011), Nandan (2010) analyzed management accounting practices according to 4 management functions.

Applying management accounting in planning: management accounting provides useful information for the planning process (Howard et al., 2013; Michael et al., 2013; Ahmad, 2012; Kaplan, 1998). The plans established by managers are usually in form of a budget. A budget report is an action plan that quantifies organizational objectives according to the financial objectives of the entity.

Applying management accounting in controlling: Ahmad (2012); Kosaiyakanont (2011); Nandan (2010); Hyvönen (2007); Kaplan (1983) pointed out that in order to help managers perform controlling function, 
the managerial accountant need to conduct specific tasks such as providing performance reports, listing all variances and evaluating performance. Management accounting analyzes variances between reality and plans or budgets occurring in the course of operation and production to improve the control system.

Applying management accounting in evaluation: According to Nandan (2010); Hyvönen (2007), Kaplan (1998) in order for the management to perform assessing function, management accounting must evaluate the effectiveness of the whole enterprise and each department regarding financial and operational aspects. From a financial perspective, management accounting generally uses basic financial indicators to support the assessment of corporate financial performance and apply these indicators in each responsibility center.

Applying management accounting in decision making: According to Michael et al. (2013), Ahmad (2012), Kosaiyakanont (2011), Nandan (2010), Hyvönen (2007), Kaplan (1998) the management accounting techniques help managers make decisions on production volume based on cost-volume-profit analysis (CVP), decision on selling price of products, short-term decisions based on relevant information.

Table 1

Measurement scales

\begin{tabular}{|c|c|c|c|}
\hline Factors & Cod & Variables & Sources \\
\hline \multirow{4}{*}{ 1. Enterprise size } & SIZE1 & Capital & \multirow{4}{*}{$\begin{array}{l}\text { Kordlouie and Hosseinpour (2018), Afirah (2018), } \\
\text { Hung (2017), Armitage and Webb (2013), Michael } \\
\text { et al. (2013), Ahmad (2012), }\end{array}$} \\
\hline & SIZE2 & Annual turnover & \\
\hline & SIZE3 & Number of employees & \\
\hline & SIZE4 & Number of products & \\
\hline \multirow{4}{*}{$\begin{array}{l}\text { 2. External } \\
\text { environment }\end{array}$} & ENVI1 & Legal environment & \multirow{4}{*}{$\begin{array}{l}\text { Afirah (2018), Lavia et al. (2015), Armitage and } \\
\text { Webb (2013), Michael et al. (2013), Ahmad (2012), } \\
\text { Abdel and Luther (2006), Chenhall (2007), Xydias- } \\
\text { Lobo et al. (2004), Laitinen (2003), Shields (1997) }\end{array}$} \\
\hline & ENVI2 & Competitive environment & \\
\hline & ENVI3 & Technological environment & \\
\hline & ENVI4 & Social-cultural environment & \\
\hline \multirow{5}{*}{$\begin{array}{l}\text { 3. Opinion of } \\
\text { mangers }\end{array}$} & OPIN1 & Awareness of management accounting & \multirow{5}{*}{$\begin{array}{l}\text { Fasesin (2015), Michael et al. (2013), Ahmad } \\
\text { (2012), Laitinen (2003), Shields (1997) }\end{array}$} \\
\hline & OPIN2 & Appreciation of management accounting & \\
\hline & OPIN3 & Willingness to apply management accounting & \\
\hline & OPIN4 & Management strategy & \\
\hline & OPIN5 & Accountants' ability to provide consultation and directions & \\
\hline \multirow{4}{*}{$\begin{array}{l}\text { 4. Organizational } \\
\text { structure }\end{array}$} & STRU1 & Organization divided into departments & \multirow{4}{*}{$\begin{array}{l}\text { Fasesin (2015), Lavia et al. (2015), Abdel and } \\
\text { Luther (2008), Chenhall (2007), Laitinen (2003) }\end{array}$} \\
\hline & STRU2 & $\begin{array}{l}\text { Each department having specific functions, rights and } \\
\text { responsibilities }\end{array}$ & \\
\hline & STRU3 & Each unit having a separate reporting system & \\
\hline & STRU4 & Each unit evaluates its own performance & \\
\hline \multirow{6}{*}{ 5. Technology } & TECH1 & Advanced manufacturing technology & \multirow{6}{*}{$\begin{array}{l}\text { Kordlouie and Hosseinpour (2018), Afirah (2018), } \\
\text { Lavia et al. (2015), Ahmad (2012), Abdel \& Luther } \\
\text { (2008), Chenhall (2007), Xydias-Lobo et al. (2004), } \\
\text { Laitinen (2003), Shields (1997) }\end{array}$} \\
\hline & TECH2 & Automation of sales & \\
\hline & TECH3 & Automation of human resources management & \\
\hline & TECH4 & Automation of accounting staff & \\
\hline & TECH5 & Total quality management & \\
\hline & TECH6 & Just in time system & \\
\hline \multirow{6}{*}{$\begin{array}{l}\text { 6. Organizational } \\
\text { culture }\end{array}$} & CULT1 & $\begin{array}{l}\text { Establishing regulations on finance, human resources, } \\
\text { reward, penalty, appointment, recruitment }\end{array}$ & \multirow{6}{*}{$\begin{array}{l}\text { Hung (2017), Erserim (2012), Chenhall (2007), } \\
\text { Xydias-Lobo et al. (2004), Laitinen (2003) }\end{array}$} \\
\hline & CULT2 & Establishing a code of conduct & \\
\hline & CULT3 & Support of managers to employees & \\
\hline & CULT4 & Cooperation of employees & \\
\hline & CULT5 & Consensus on development goals & \\
\hline & CULT6 & Building internal and external corporate image & \\
\hline \multirow{4}{*}{$\begin{array}{l}\text { 7. Management } \\
\text { accounting } \\
\text { application }\end{array}$} & APMA1 & Application in planning & \multirow{4}{*}{$\begin{array}{l}\text { Armitage and Webb (2013); Michael et al. (2012); } \\
\text { Ahmad (2012); Kosaiyakanont (2011); Nandan } \\
\text { (2010); Hyvönen (2007); Pierce and O`Dea (1998); } \\
\text { Bruggeman et al. (1996); Birkett et al. (1992); } \\
\text { Scarbrough et al. (1991) }\end{array}$} \\
\hline & APMA2 & Application in controlling & \\
\hline & APMA3 & Application in evaluation & \\
\hline & APMA4 & Application in decision making & \\
\hline
\end{tabular}

\subsection{Conceptual framework and research hypotheses}

\section{Conceptual framework}

Based on the literature review, conceptual framework of the research on factors affecting management accounting application in Vietnamese enterprises is established as follows: 


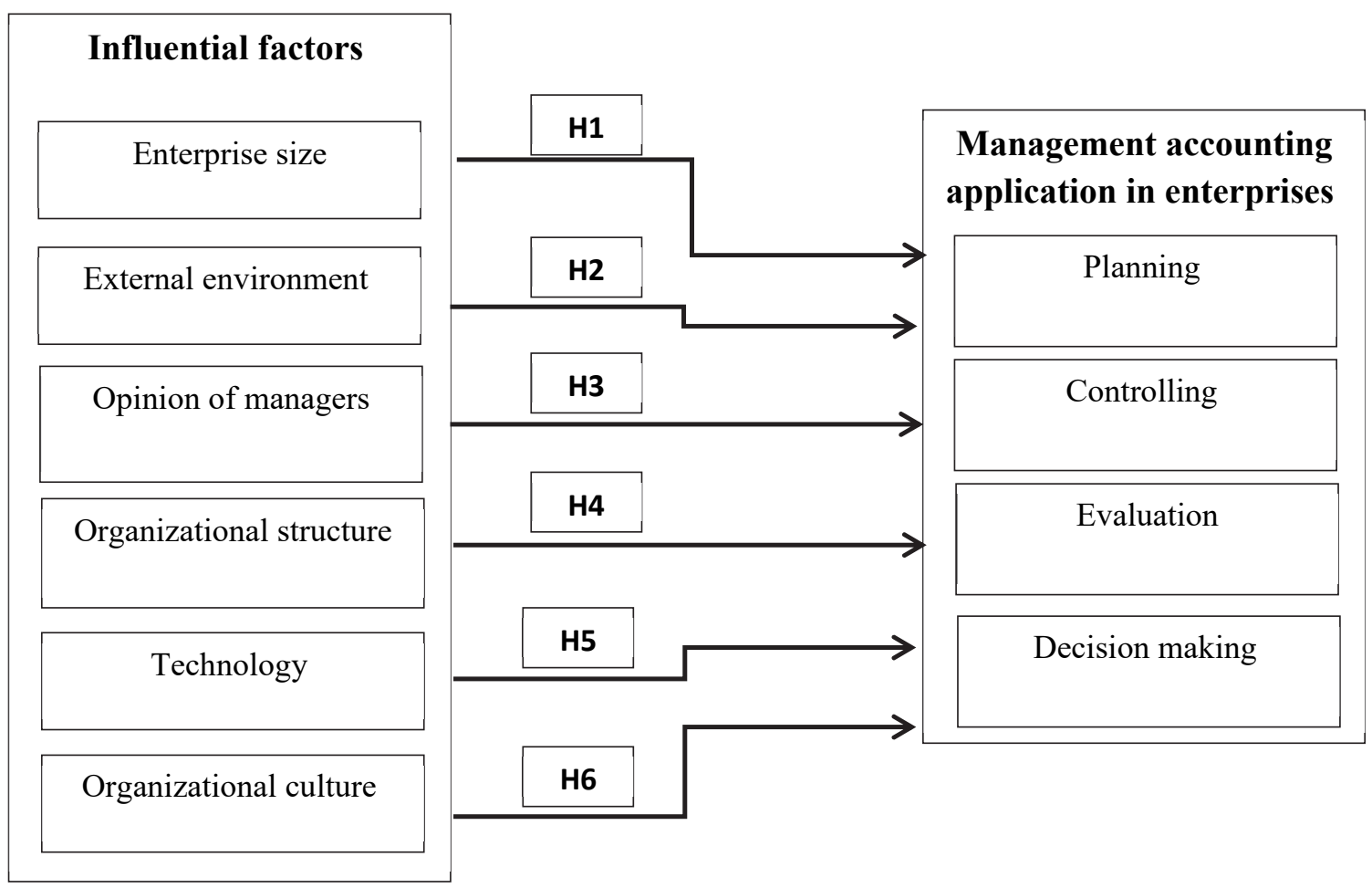

Fig. 1. Conceptual framework

\section{Research hypotheses}

Based on the conceptual framework and discussion with experts, 6 research hypotheses are proposed as follows:

Hypothesis $\mathrm{H}_{1}$ - There is a positive relationship between enterprise size and management accounting application in enterprises.

Hypothesis $\mathrm{H}_{2}-$ There is a negative relationship between environmental instability /uncertainty and management accounting application in enterprises.

Hypothesis $\mathrm{H}_{3}-$ There is a positive relationship between opinion of managers on management accounting and management accounting application in enterprises.

Hypothesis $\mathrm{H}_{4}$ - There is a positive relationship between strictness of organizational structure and management accounting application in enterprises.

Hypothesis $\mathrm{H}_{5}$ - There is a positive relationship between the amount of advanced technology used in enterprises and the level of success of management accounting application.

Hypothesis $\mathrm{H}_{6}-$ There is a positive relationship between development of organizational culture and management accounting application in enterprises.

\section{Regression equation}

Based on the above analysis, regression equation reflecting the relationship between factors and management accounting application is presented as follows:

$$
\mathrm{APMA}_{i}=\alpha+\beta_{1} \mathrm{SIZE}_{\mathrm{i}}+\beta_{2} \mathrm{ENVI}_{\mathrm{i}}+\beta_{3} \mathrm{OPIN}_{\mathrm{i}}+\beta_{4} \mathrm{STRU}_{\mathrm{i}}+\beta_{5} \mathrm{TECH}_{\mathrm{i}}+\beta_{6} \mathrm{CULT}_{\mathrm{i}}+\varepsilon
$$

where $\alpha$ is constant, $\beta_{i}$ represents the coefficient of variable and $\varepsilon_{i}$ denotes residual.

Independent variables: Enterprise size (SIZE); External environment (ENVI); Opinion of managers (OPIN); Organizational structure (STRU); Technology (TECH); Organizational culture (CULT). 
Dependent variable: Application of management accounting of enterprises I (APMA $)$

\subsection{Questionnaire}

In order to collect data for the research on the impact of factors on the application of management accounting in enterprises in Vietnam, research questionnaire was established based on literature review and consultation with experts was conducted to check and confirm the contents of the questionnaire. All variables were measured using a 5-point Likert scale in which $1=$ "strongly disagree" and $5=$ "strongly agree". The questionnaire was divided into 3 sections. Specifically, part 1 was general information of respondent, part 2 was general information of enterprise, and part 3 was the main part including (i) The actual situation of management accounting application in enterprise; (ii) The actual situation of management accounting techniques applied in enterprises; (iii) Factors affecting the application of management accounting in enterprise.

\subsection{Quantitative research}

Sample size: Hair et al. (1998) assumed that in order to conduct Exploratory Factor Analysis (EFA), the minimum sample size is 50 . The sample size can be determined by the formula: $\mathrm{n} \geq 50+8 \mathrm{k}$, in which $\mathrm{k}$ is the number of independent variables in the model. In this study, the number of independent variables is 6 so the sample size is $n \geq 50+8 \times 6=98$ which is appropriate for EFA and regression analysis. Therefore, the sample size of 120 is appropriate in this study.

Data collection: Data was collected by sending questionnaires to respondents directly, via email and social media. Convenience sampling technique was applied due to its speed and efficiency.

Processing data: Cleaning data was conducted by eliminating invalid and blank answers. Then data was analyzed with the support of SPSS 22. Specific techniques include: Descriptive statistics including frequencies, measures of central tendency; Analysis of Variance including t-tests, F-tests; Reliability test using Cronbach Alpha coefficients; Exploratory Factor Analysis (EFA): KMO and Bartlett's test; Regression analysis was used to check model fit, correlation, residual to identify the relationship between variables.

\subsection{Characteristics of respondents}

For the purpose of this study, respondents were classified into groups regarding the type of enterprise, business sector, enterprise size. The total number of questionnaires distributed was 120, however, only 102 valid answers were received. The questionnaires were sent to chief accountants and directors of enterprises. If there was a difference in the answers between the director and chief accountant, it would be clear in the process of data cleaning. Therefore, data used for analysis was relatively reliable. The characteristics of surveyed respondents are shown in the table below:

Table 2

Characteristics of respondents

\begin{tabular}{|c|c|c|c|c|}
\hline & & Characteristics & Frequency & Percent $(\%)$ \\
\hline \multirow{3}{*}{1.} & \multirow{3}{*}{ Gender } & Male & 16 & 15.7 \\
\hline & & Female & 86 & 84.3 \\
\hline & & Total & 102 & 100.0 \\
\hline \multirow{4}{*}{2.} & \multirow{4}{*}{ Academic Qualification } & Bachelor & 62 & 60.8 \\
\hline & & Master & 39 & 38.2 \\
\hline & & Doctor & 1 & 1.0 \\
\hline & & Total & 102 & 100.0 \\
\hline \multirow{6}{*}{3.} & \multirow{6}{*}{ Working Experience } & Up to 5 years & 28 & 27.5 \\
\hline & & 6 to 10 years & 23 & 22.5 \\
\hline & & 11 to 15 years & 22 & 21.6 \\
\hline & & 16 to 20 years & 27 & 26.5 \\
\hline & & Over 20 years & 2 & 2.0 \\
\hline & & Total & 102 & 100.0 \\
\hline \multirow{4}{*}{4.} & \multirow{4}{*}{ Job title } & Chief accountant & 52 & 51.0 \\
\hline & & Internal accounting & 39 & 38.2 \\
\hline & & Manager & 11 & 10.8 \\
\hline & & Total & 102 & 100.0 \\
\hline
\end{tabular}


The results in the Table 2 show that the total number of respondents is 102, in which 16 people are male $(15.7 \%)$, and 86 people are female $(84.3 \%)$. This is a common ratio of gender in accounting jobs. Regarding the qualifications of respondents, the results show that $60 \%$ of respondent have a bachelor's degree, $40 \%$ have a master's degree. Regarding work experience, only 2 accountants have more than 20 years of work experience. Regarding position, most respondents are chief accountants (52 people accounting for $51 \%$ ), followed by internal accountants (39 people accounting for $38.2 \%$ ), and only 11 people are directors (accounting for 10\%).

Table 3

General characteristics of firms

\begin{tabular}{|c|c|c|c|}
\hline Variables & & Frequency & Percent $(\%)$ \\
\hline \multirow{5}{*}{ 1. Types of firms } & Joint-stock company & 37 & 36.3 \\
\hline & Limited liability company & 42 & 41.2 \\
\hline & Private company & 15 & 14.7 \\
\hline & Joint-venture company & 8 & 7.8 \\
\hline & Total & 102 & 100.0 \\
\hline \multirow{5}{*}{ 2. Sectors } & Manufacturing & 50 & 49.0 \\
\hline & Trading & 15 & 14.7 \\
\hline & Services & 24 & 23.5 \\
\hline & Construction & 13 & 12.7 \\
\hline & Total & 102 & 100.0 \\
\hline \multirow{6}{*}{ 3. Location of Head office } & Northern Vietnam & 26 & 25.5 \\
\hline & Central Vietnam & 27 & 26.5 \\
\hline & Southern Vietnam & 26 & 25.5 \\
\hline & Other countries & 14 & 13.7 \\
\hline & Others & 9 & 8.8 \\
\hline & Total & 96 & 94.1 \\
\hline \multirow{6}{*}{ 4. Firm age (in years) } & Up to 5 years & 8 & 7.8 \\
\hline & 6 to 10 years & 15 & 14.7 \\
\hline & 11 to 15 years & 32 & 31.4 \\
\hline & 16 to 20 years & 10 & 9.8 \\
\hline & Over 20 years & 37 & 36.3 \\
\hline & Total & 102 & 100.0 \\
\hline
\end{tabular}

(Source: Compiled by the authors based on research results)

The classification of enterprises into groups including type of enterprise, sectors, geographic area, firm age was to ensure the representativeness of the research sample. However, in the process of collecting data, there exists differences from the initial plan. Specifically, regarding type of enterprise, the results show that most companies were limited liability companies and joint stock companies, accounting for $41 \%$ and $36 \%$ respectively, private enterprises account for $15 \%$ and joint ventures take up $8 \%$. The manufacturing sector accounts for the largest proportion (49\%), followed by the service sector with $24 \%$, and the trading and service sectors have the smallest proportions. Regarding length of operation, the surveyed enterprises are evenly distributed in the North, Center and South of Vietnam with proportion ranging from $30 \%$ to 34\%. Regarding firm age, most enterprises has operated from 15 to 20 years $(36.3 \%)$, only $31.45 \%$ of companies has operated from 10 years to 15 years, 15 enterprises had operated for less than 10 years and 8 enterprises has operated for less than 5 years.

\section{Research results}

\subsection{Descriptive statistics of variables}

The enterprise size is measured by variables including annual turnover, capital, number of employees, number of products. These variables have mean values ranging from 2.69 to 3.59. This indicates that measurement scales are appropriate to measure enterprise size factor and have impact on management accounting application. Business environment is measured by 4 items including the legal, sociocultural, technological and competitive environment. These variables have mean values ranging from 3.65 to 3.75. Particularly, the legal environment has the highest mean value, the competitive environment has the lowest mean value. Opinion of managers is measured by 5 items reflecting the increasing level of opinion. These variables have mean values ranging from 4.09 to 4.26 . The management strategy is a new variable added through the in-depth interview of the directors and chief accountants, this variable has a mean value of 3.37. The organizational structure is considered to have 
a strong influence on the application of management accounting and the basis for a successful management accounting system. This factor is measured by 4 variables including division of departments (3.86), establishing functions, rights and responsibilities of each department (3.83), each department evaluating its own performance periodically (3.72), each department having separate reporting system (3.62).

\section{Table 4}

Descriptive statistics of variables

\begin{tabular}{|c|c|c|c|c|c|c|c|}
\hline No. & Cod & Variables & $\mathbf{N}$ & Min & Max & Mean & $\begin{array}{c}\text { Std. } \\
\text { Deviation }\end{array}$ \\
\hline 1 & SIZE1 & Capital & 102 & 1 & 5 & 3.59 & 1.075 \\
\hline 2 & SIZE2 & Annual turnover & 99 & 1 & 5 & 3.24 & 1.098 \\
\hline 3 & SIZE3 & Number of employees & 102 & 1 & 5 & 3.1 & 1.255 \\
\hline 4 & SIZE4 & Number of products & 100 & 1 & 5 & 2.69 & 1.22 \\
\hline 5 & ENVI1 & Legal environment & 102 & 3 & 5 & 3.75 & 0.575 \\
\hline 6 & ENVI2 & Competitive environment & 102 & 3 & 5 & 3.65 & 0.655 \\
\hline 7 & ENVI3 & Technological environment & 102 & 2 & 5 & 3.67 & 0.722 \\
\hline 8 & ENVI4 & Social-cultural environment & 102 & 2 & 5 & 3.65 & 0.713 \\
\hline 9 & OPIN1 & Awareness of management accounting & 102 & 2 & 5 & 4.24 & 0.76 \\
\hline 10 & OPIN2 & Appreciation of management accounting & 102 & 2 & 5 & 4.26 & 0.688 \\
\hline 11 & OPIN3 & Willingness to apply management accounting & 102 & 3 & 5 & 4.13 & 0.608 \\
\hline 12 & OPIN4 & Management strategy & 102 & 3 & 5 & 4.09 & 0.676 \\
\hline 13 & OPIN5 & Accountants' ability provide consultation and directions & 102 & 2 & 5 & 3.73 & 0.677 \\
\hline 14 & STRU1 & Organization divided into departments & 102 & 2 & 5 & 3.86 & 0.564 \\
\hline 15 & STRU2 & $\begin{array}{l}\text { Each department having specific functions, rights and } \\
\text { responsibilities }\end{array}$ & 102 & 2 & 5 & 3.83 & 0.676 \\
\hline 16 & STRU3 & Each unit having a separate reporting system & 102 & 2 & 5 & 3.72 & 0.666 \\
\hline 17 & STRU4 & Each unit evaluates its own performance & 102 & 2 & 5 & 3.62 & 0.732 \\
\hline 18 & TECH1 & Advanced manufacturing technology & 102 & 1 & 5 & 3.72 & 0.894 \\
\hline 19 & TECH2 & Automation of sales & 102 & 1 & 5 & 3.63 & 1.004 \\
\hline 20 & TECH3 & Automation of human resources management & 102 & 1 & 5 & 3.55 & 1.05 \\
\hline 21 & TECH4 & Automation of accounting staff & 102 & 1 & 5 & 3.41 & 1.129 \\
\hline 22 & TECH5 & Total quality management & 101 & 1 & 5 & 3.27 & 1.207 \\
\hline 23 & TECH6 & Just in time system & 102 & 1 & 5 & 3.16 & 1.208 \\
\hline 24 & CULT1 & $\begin{array}{l}\text { Establishing regulations on finance, human resources, } \\
\text { reward, penalty, appointment, recruitment }\end{array}$ & 102 & 2 & 5 & 3.58 & 0.696 \\
\hline 25 & CULT2 & Establishing a code of conduct & 102 & 2 & 5 & 3.52 & 0.767 \\
\hline 26 & CULT3 & Support of managers to employees & 102 & 2 & 5 & 3.58 & 0.71 \\
\hline 27 & CULT4 & Cooperation of employees & 102 & 3 & 5 & 3.65 & 0.591 \\
\hline 28 & CULT5 & Consensus on development goals & 102 & 2 & 5 & 3.64 & 0.672 \\
\hline 29 & CULT6 & Building internal and external corporate image & 102 & 3 & 5 & 3.75 & 0.62 \\
\hline 30 & APMA1 & Application in planning & 102 & 2 & 5 & 3.43 & 0.668 \\
\hline 31 & APMA2 & Application in controlling & 102 & 2 & 5 & 3.41 & 0.709 \\
\hline 32 & APMA3 & Application in evaluation & 102 & 2 & 5 & 3.43 & 0.85 \\
\hline 33 & APMA4 & Application in decision making & 102 & 2 & 5 & 3.56 & 0.896 \\
\hline
\end{tabular}

In general, all 4 variables have impacts on the management accounting application in enterprises. Technology variable is considered in the following aspects: using advanced manufacturing technology; automation of sales; adopting total quality management system; applying just in time system. These variables have relatively high mean values ranging from 3.16 to 3.72 . Organizational culture is measured by 6 variables. These variables have relatively high mean values ranging from 3.52 to 3.75 . In particular, enterprises agree that establishing internal and external corporate image is the most important thing with a mean value of 3.75. Code of conduct receives less attention and is mainly established in large enterprises, state-owned enterprises or joint ventures. In brief, variables are appropriate to measure organizational culture. Management accounting application is examined in 4 management functions including: planning, controlling, evaluation and decision making. In which, decision making function has the highest mean value of 3.56. Applying management accounting in controlling costs has the lowest mean value of 3.41 . 


\subsection{Reliability test (Cronbach's Alpha)}

In order to examine the reliability of measurement scales, the Cronbach's alpha test was conducted. Firstly, reliability of each item of variables was tested. Regarding management accounting application, this factor is measured by 4 variables so any item with Cronbach's Alpha coefficient less than 0.3 will be eliminated, and reliability test will continue with the remaining variables. The results show that "Applying management accounting in decision making" with Cronbach's Alpha coefficient $=0.218$ $<0.3$ is removed.

\section{Table 5}

Reliability test of dependent variable

\begin{tabular}{|c|c|c|c|c|c|c|c|}
\hline \multirow[b]{2}{*}{ No. } & \multirow[b]{2}{*}{ Cod } & \multirow[b]{2}{*}{ Variables } & \multicolumn{2}{|c|}{ Number of variables } & \multirow[b]{2}{*}{$\begin{array}{c}\text { Cronbach's } \\
\text { Alpha }\end{array}$} & \multirow[b]{2}{*}{$\begin{array}{l}\text { Corrected } \\
\text { Item_Total } \\
\text { Correlation }\end{array}$} & \multirow[b]{2}{*}{$\begin{array}{l}\text { Removed } \\
\text { item }\end{array}$} \\
\hline & & & $\begin{array}{c}\text { Before } \\
\text { deleting item }\end{array}$ & $\begin{array}{c}\text { After } \\
\text { deleting } \\
\text { item }\end{array}$ & & & \\
\hline 1. & APMA1 & Planning & 8 & 8 & 0.877 & $0.505-0.781$ & \\
\hline 2. & APMA2 & Controlling & 4 & 4 & 0.861 & $0.630-0.782$ & \\
\hline 3. & APMA3 & Evaluation & 5 & 5 & 0.814 & $0.407-0.873$ & \\
\hline 4. & APMA4 & Decision making & 4 & 3 & 0.868 & $0.817-0.891$ & $\begin{array}{c}\text { Continue or } \\
\text { stop }\end{array}$ \\
\hline
\end{tabular}

The results show that the 4 variables measuring management accounting application in enterprises have Cronbach's Alpha coefficients over 0.8 , the total correlation coefficient of each scale ranging from 0.548 to 0.891 . This shows that all factors and scales are reliable and can be used for Exploratory Factor Analysis. Reliability test was conducted with measurement scales of factors affecting management accounting application in enterprises. The results are shown in the Table 6.

Table 6

Reliability test of independent variables

\begin{tabular}{|c|c|c|c|c|c|c|c|}
\hline \multirow[b]{2}{*}{ No. } & \multirow[b]{2}{*}{ Cod } & \multirow[b]{2}{*}{ Variables } & \multicolumn{2}{|c|}{$\begin{array}{c}\text { The number of observed } \\
\text { variables }\end{array}$} & \multirow{2}{*}{$\begin{array}{l}\text { Cronbach's } \\
\text { Alpha }\end{array}$} & \multirow{2}{*}{$\begin{array}{c}\text { Corrected } \\
\text { Item_Total } \\
\text { Correlation }\end{array}$} & \multirow[b]{2}{*}{ Removed item } \\
\hline & & & $\begin{array}{c}\text { Before } \\
\text { deleting } \\
\text { item }\end{array}$ & $\begin{array}{c}\text { After } \\
\text { deleting } \\
\text { item }\end{array}$ & & & \\
\hline 1 & SIZE & Enterprise size & 4 & 4 & 0.747 & $0.438-0.598$ & \multirow{7}{*}{$\begin{array}{c}\text { Organization } \\
\text { divided into } \\
\text { departments }\end{array}$} \\
\hline 2 & ENVI & External environment & 4 & 4 & 0.748 & $0.436-0.632$ & \\
\hline 3 & OPIN & Opinion of managers & 5 & 5 & 0.841 & $0.499-0.797$ & \\
\hline 4 & STRU & Organizational structure & 4 & 3 & 0.761 & $0.552-0.646$ & \\
\hline 5 & TECH & Technology & 6 & 6 & 0.877 & $0.514-0.779$ & \\
\hline 6 & CULT & $\begin{array}{l}\text { Organizational culture } \\
\text { Dependent variable }\end{array}$ & 6 & 6 & 0.894 & $0.664-0.811$ & \\
\hline 7 & APMA & $\begin{array}{l}\text { Application of management } \\
\text { accounting }\end{array}$ & 4 & 4 & 0.875 & $0.636-0.781$ & \\
\hline
\end{tabular}

(Source: compilation of data processed by SPSS 20)

It can be seen that there are 6 independent variables and 1 dependent variable with a total of 32 measurement scales. After running Cronbach's Alpha test for the first time for each variable, variable "Organization divided into departments" was removed because Cronbach's Alpha coefficient $=0.245$ $<0.3$. The Cronbach's Alpha coefficients of variables range from 0.741 to 0.894 and the total correlation coefficients of variables range from 0.436 to 0.811 . This shows that the factors and measurement scales are reliable and can be used in EFA.

\subsection{Exploratory factor analysis (EFA)}

This study has 6 independent variables with 29 observed variables and 1 dependent variable with 4 observed variables, sample size is 120 (satisfied the requirement of sample size $\geq 100$ and $\leq 350$ ), so Factor loading is set at 0.55 . Furthermore, $\mathrm{KMO}=0.66$ which indicates that factor analysis is 
appropriate for research data. In addition, significance value $=0,000 \leq 0.5$ which means that the variables are highly correlated, providing a reasonable basis for factor analysis.

Table 7

KMO and Bartlett's Test

\begin{tabular}{lll}
\hline Kaiser-Meyer-Olkin Measure of Sampling Adequacy. & .646 \\
& Approx. Chi-Square & 1326.419 \\
Bartlett's Test of Sphericity & df & 253 \\
& Sig. & .000 \\
\hline
\end{tabular}

(Source: compilation of data processed by SPSS 20)

The Total Variance Explained table shows that the cumulative percentage of variance accounted for by factors is $70.67 \%$. This indicates that $70.67 \%$ of the total variance is accounted for by observed variables. In addition, a factor with eigenvalue $<1.0$ explains less information than a single item would have explained. Therefore, only factors with Eigenvalue $>1$ and cumulative percentage $\geq 50 \%$ can be extracted (Table 8). The rotated component matrix table represents all rotated factor loadings which are greater than 0.55 . The results are shown in the Table 9.

\section{Table 8}

Total Variance Explained

\begin{tabular}{|c|c|c|c|c|c|c|c|c|c|}
\hline \multirow[t]{2}{*}{ Component } & \multicolumn{3}{|c|}{ Initial Eigenvalues } & \multicolumn{3}{|c|}{$\begin{array}{l}\text { Extraction Sums of Squared } \\
\text { Loadings }\end{array}$} & \multicolumn{3}{|c|}{$\begin{array}{l}\text { Rotation Sums of Squared } \\
\text { Loadings }\end{array}$} \\
\hline & Total & $\begin{array}{c}\% \text { of } \\
\text { Variance }\end{array}$ & Cumulative $\%$ & Total & $\begin{array}{c}\% \text { of } \\
\text { Variance }\end{array}$ & Cumulative $\%$ & Total & $\begin{array}{c}\% \text { of } \\
\text { Variance }\end{array}$ & Cumulative $\%$ \\
\hline 1 & 4.849 & 21.084 & 21.084 & 4.849 & 21.084 & 21.084 & 4.003 & 17.406 & 17.406 \\
\hline 2 & 3.450 & 14.999 & 36.083 & 3.450 & 14.999 & 36.083 & 3.498 & 15.210 & 32.616 \\
\hline 3 & 2.634 & 11.451 & 47.534 & 2.634 & 11.451 & 47.534 & 2.367 & 10.290 & 42.906 \\
\hline 4 & 2.342 & 10.185 & 57.718 & 2.342 & 10.185 & 57.718 & 2.359 & 10.258 & 53.164 \\
\hline 5 & 1.648 & 7.164 & 64.882 & 1.648 & 7.164 & 64.882 & 2.199 & 9.563 & 62.726 \\
\hline 6 & 1.333 & 5.795 & 70.677 & 1.333 & 5.795 & 70.677 & 1.829 & 7.951 & 70.677 \\
\hline 7 & .976 & 4.243 & 74.920 & & & & & & \\
\hline 8 & .776 & 3.376 & 78.296 & & & & & & \\
\hline 9 & .718 & 3.123 & 81.420 & & & & & & \\
\hline 10 & .646 & 2.808 & 84.228 & & & & & & \\
\hline 11 & .588 & 2.558 & 86.786 & & & & & & \\
\hline 12 & .477 & 2.075 & 88.861 & & & & & & \\
\hline 13 & .455 & 1.978 & 90.839 & & & & & & \\
\hline 14 & .406 & 1.766 & 92.605 & & & & & & \\
\hline 15 & .325 & 1.413 & 94.018 & & & & & & \\
\hline 16 & .310 & 1.348 & 95.365 & & & & & & \\
\hline 17 & .274 & 1.191 & 96.556 & & & & & & \\
\hline 18 & .219 & .953 & 97.509 & & & & & & \\
\hline 19 & .165 & .718 & 98.227 & & & & & & \\
\hline 20 & .155 & .672 & 98.899 & & & & & & \\
\hline 21 & .124 & .537 & 99.436 & & & & & & \\
\hline 22 & .095 & .412 & 99.848 & & & & & & \\
\hline 23 & .035 & .152 & 100.000 & & & & & & \\
\hline
\end{tabular}

Before conducting EFA, the study was designed with 6 independent variables and 29 observed variables. After running EFA for the first time, there are 6 independent variables with only 23 observed variables since 6 observed variables were removed during the analysis because their factor loadings factor is smaller than 0.55. In particular, the first 5 observed variables measuring "Opinion of managers" and the last observed variable measuring "Organizational structure" are removed, the remaining 23 variables are sorted into 6 factors. The specific results are presented as follows: 
Factor 1: Organizational culture includes 6 observed variables CULT1, CULT2, CULT4, CULT5, CULT6 with loading factors ranging from 0.660 to 0.879 .

Factor 2: Technology includes 4 observed variables TECH1, TECH2, TECH5, TECH6 with loading factor ranging from 0.776 to 0.909 .

Factor 3: Business environments include 4 observed variables ENVI1, ENVI2, ENVI3, ENVI4 with loading factor ranging from $0.698-0.792$.

Factor 4: Enterprise size includes 4 observed variables SIZE1, SIZE2, SIZE3, SIZE4 with loading factor ranging from $0.642-0.799$,

Factor 5: Organizational structure includes 3 observed variables STRU1, STRU2, STRU3 with loading factor ranging from $0.761-0.812$

Factor 6: Human Resources Operations includes 2 observed variables TECH3, TECH4 with loading factor ranging from $0.716-0.830$.

\section{Table 9}

\section{Rotated Component Matrix ${ }^{\mathrm{a}}$}

\begin{tabular}{|c|c|c|c|c|c|c|c|}
\hline \multirow{2}{*}{ Cod } & \multirow{2}{*}{ Variables } & \multicolumn{6}{|c|}{ Component } \\
\hline & & 1 & 2 & 3 & 4 & 5 & 6 \\
\hline CULT2 & Establishing a code of conduct & 0.879 & & & & & \\
\hline CULT1 & $\begin{array}{l}\text { Establishing regulations, policies on finance, human resources, } \\
\text { rewards, fines }\end{array}$ & 0.834 & & & & & \\
\hline CULT5 & Consensus on development goals & 0.819 & & & & & \\
\hline CULT3 & Support of managers to employees & 0.789 & & & & & \\
\hline CULT4 & Cooperation of employees & 0.731 & & & & & \\
\hline CULT6 & Establishing internal and external corporate image & 0.66 & & & & & \\
\hline TECH6 & Just in time system & & 0.909 & & & & \\
\hline TECH5 & Total quality management & & 0.892 & & & & \\
\hline TECH1 & Advanced manufacturing technology & & 0.876 & & & & \\
\hline TECH2 & Applying automation of sales & & 0.776 & & & & \\
\hline ENVI2 & Competitive environment & & & 0.792 & & & \\
\hline ENVI3 & Technological environment & & & 0.785 & & & \\
\hline ENVI4 & Socio-cultural environment & & & 0.709 & & & \\
\hline ENVI1 & Legal environment & & & 0.698 & & & \\
\hline SIZE3 & The number of employees & & & & 0.799 & & \\
\hline SIZE1 & Annual turnover & & & & 0.798 & & \\
\hline SIZE2 & Capital & & & & 0.727 & & \\
\hline SIZE4 & The number of products & & & & 0.642 & & \\
\hline STRU4 & Each department having separate reporting system & & & & & 0.812 & \\
\hline STRU3 & Each department evaluating its own performance & & & & & 0.781 & \\
\hline STRU2 & $\begin{array}{l}\text { Regulating functions, rights and responsibilities of each } \\
\text { department }\end{array}$ & & & & & 0.761 & \\
\hline TECH3 & Automation of accounting staff & & & & & & 0.83 \\
\hline TECH4 & Automation of human resources management & & & & & & 0.716 \\
\hline $\begin{array}{l}\text { Extraction } \\
\text { Rotation I } \\
\text { a. Rotatio }\end{array}$ & $\begin{array}{l}\text { Tethod: Principal Component Analysis. } \\
\text { thod: Varimax with Kaiser Normalization. } \\
\text { onverged in } 6 \text { iterations. }\end{array}$ & & & & & & \\
\hline
\end{tabular}

\subsection{Regression analysis}

\section{Correlation analysis}

The correlation analysis was conducted between 6 independent variables and dependent variable (APMA). The purpose of correlation analysis is to determine the strength of the linear relationship between the dependent variable and the independent variables, and test autocorrelation before performing regression analysis. The correlation test results are shown in Table 10. The results indicate independent variables including ENVI, SIZE, CULT, STRU, TECH, OPPE are correlated with dependent variable APMA with significance value $<0.05$. The variable ENVI is negatively correlated with the dependent variable, the remaining variables are positively correlated with the dependent variable. 
Table 10

Correlations_Spearman's rho

\begin{tabular}{|c|c|c|c|c|c|c|c|c|}
\hline & & ENVI & APMA & SIZE & CULT & STRU & TECH & OPPE \\
\hline \multirow{3}{*}{ ENVI } & Correlation Coefficient & 1 & -0.084 & 0.165 & 0.107 & 0.064 & 0.156 & 0.165 \\
\hline & Sig. (2-tailed) & 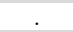 & 0.003 & 0.107 & 0.286 & 0.521 & 0.12 & 0.098 \\
\hline & $\mathrm{N}$ & 102 & 102 & 97 & 102 & 102 & 101 & 102 \\
\hline \multirow{3}{*}{ APMA } & Correlation Coefficient & -0.084 & 1 & 0.192 & 0.194 & 0.039 & $.256^{* *}$ & $.225^{*}$ \\
\hline & Sig. (2-tailed) & 0.003 & . & 0.04 & 0.021 & 0.099 & 0.01 & 0.023 \\
\hline & $\mathrm{N}$ & 102 & 102 & 97 & 102 & 102 & 101 & 102 \\
\hline \multirow{3}{*}{ SIZE } & Correlation Coefficient & 0.165 & 0.192 & 1 & 0.128 & 0.051 & 0.11 & 0.049 \\
\hline & Sig. (2-tailed) & 0.107 & 0.04 & & 0.211 & 0.622 & 0.286 & 0.63 \\
\hline & $\mathrm{N}$ & 97 & 97 & 97 & 97 & 97 & 96 & 97 \\
\hline \multirow{3}{*}{ CULT } & Correlation Coefficient & 0.107 & 0.194 & 0.128 & 1 & 0.138 & 0.185 & $.379^{* *}$ \\
\hline & Sig. (2-tailed) & 0.286 & 0.021 & 0.211 & & 0.166 & 0.064 & 0 \\
\hline & $\mathrm{N}$ & 102 & 102 & 97 & 102 & 102 & 101 & 102 \\
\hline \multirow{3}{*}{ STRU } & Correlation Coefficient & 0.064 & 0.039 & 0.051 & 0.138 & 1 & $.227^{*}$ & $.260^{* *}$ \\
\hline & Sig. (2-tailed) & 0.521 & 0.099 & 0.622 & 0.166 & . & 0.022 & 0.008 \\
\hline & $\mathrm{N}$ & 102 & 102 & 97 & 102 & 102 & 101 & 102 \\
\hline \multirow{3}{*}{ ТЕCH } & Correlation Coefficient & 0.156 & $.256^{* *}$ & 0.11 & 0.185 & $.227^{*}$ & 1 & $.541^{* *}$ \\
\hline & Sig. (2-tailed) & 0.12 & 0.01 & 0.286 & 0.064 & 0.022 & 1 & 0 \\
\hline & $\mathrm{N}$ & 101 & 101 & 96 & 101 & 101 & 101 & 101 \\
\hline \multirow{3}{*}{ OPPE } & Correlation Coefficient & 0.165 & $.225^{*}$ & 0.049 & $.379^{* *}$ & $.260^{* *}$ & $.541^{* *}$ & 1 \\
\hline & Sig. (2-tailed) & 0.098 & 0.023 & 0.63 & 0 & 0.008 & 0 & 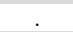 \\
\hline & $\mathrm{N}$ & 102 & 102 & 97 & 102 & 102 & 101 & 102 \\
\hline
\end{tabular}

This is consistent with the proposed research hypotheses. Therefore, all hypotheses from $\mathrm{H}_{1}$ to $\mathrm{H}_{6}$ are accepted. However, the Pearson correlation coefficient between variables are relatively low $(<0.9)$ reflects poor correlation between the independent variables and dependent variable. The independent variables are not correlated with each other because Significance values are $>0.05$. The results of correlation matrix are consistent with the EFA table above. The correlation analysis between the dependent and independent variables shows that research data is appropriate for regression analysis to investigate the factors affecting the application of management accounting in enterprises.

\section{Regression analysis}

The regression results between independent variables ENVI, SIZE, CULT, STRU, TECH, OPPE and dependent variable APMA are shown in Table 11.

Table 11

Model Summary ${ }^{\mathbf{b}}$

\begin{tabular}{lccccc}
\hline Model & R & R Square & Adjusted R Square & Std. Error of the Estimate & Durbin-Watson \\
\hline 1 & $.653^{\mathrm{a}}$ & .625 & .666 & .63063 & 1.172 \\
\hline
\end{tabular}

a. Predictors: (Constant), OPPE, SIZE, STRU, ENVI, CULT, TECH

b. Dependent Variable: APMA

Adjusted R Square $=0.666($ Table 11), which means that 6 independent variables can explain $66.6 \%$ of variance of management accounting application in enterprises, the remaining $33.4 \%$ may be accounted for by other variables or random errors. The Anova analysis points out the significance value fit for the research data and can be used to predict the impact of variables with significant accuracy (Sig. $<0.05)$. In addition, each factor in the model is analyzed and tested to examine their impact on dependent variables.

Table 12

Coefficients $^{\mathrm{a}}$

\begin{tabular}{|c|c|c|c|c|c|c|c|}
\hline \multirow[t]{2}{*}{ Model } & \multicolumn{2}{|c|}{ Unstandardized Coefficients } & \multirow{2}{*}{$\begin{array}{c}\begin{array}{c}\text { Standardized } \\
\text { Coefficients }\end{array} \\
\text { Beta } \\
\end{array}$} & \multirow[t]{2}{*}{$\mathbf{t}$} & \multirow[t]{2}{*}{ Sig. } & \multicolumn{2}{|c|}{ Collinearity Statistics } \\
\hline & B & Std. Error & & & & Tolerance & VIF \\
\hline (Constant) & 3.668 & .776 & & 4.726 & .000 & & \\
\hline ENVI & -.158 & .131 & -.046 & .447 & .046 & .945 & 1.059 \\
\hline SIZE & .181 & .089 & .210 & -2.040 & .044 & .931 & 1.074 \\
\hline 1 CULT & .291 & .129 & .375 & .703 & .004 & .863 & 1.159 \\
\hline STRU & .201 & .125 & .269 & 1.603 & .012 & .887 & 1.128 \\
\hline TECH & .136 & .079 & .203 & 1.730 & .017 & .714 & 1.400 \\
\hline OPPE & .034 & .086 & .046 & .395 & .014 & .718 & 1.393 \\
\hline
\end{tabular}


VIF coefficients of 6 independent variables range from 1.059 to 1.400, which are smaller than 2, thus, there is no multicollinearity (Table 12). Furthermore, Durbin - Waston $=1.172$ which indicates that there is no autocorrelation. Therefore, the regression equation reflecting relationship between independent variables and dependent variable is presented as follows:

$A P M A=-0.046 \times E N V I+0.210 \times S I Z E+0.375 \times C U L T+0.269 \times S T R U+0.203 \times T E C H+0.046 \times O P P E$

\section{Discussion and conclusion}

\subsection{Business environment}

The research results show that the business environment is adversely associated with management accounting application, however, with small impact (- 0.046). In particular, competitive environment has the greatest impact. The higher the degree of competition regarding competitors, market share/revenue, prices, the number of competitors in the same market segment, the lower the level of management accounting application. This result confirms hypothesis $\mathrm{H}_{2}$ and is consistent previous studies of Afirah (2018), Lavia et al. (2015), Armitage and Webb (2013), Michael et al. (2013). This can be explained by the fact that in a highly competitive environment along with instable legal systems, declining culture, it is difficult for enterprises to focus on management accounting techniques. Currently, Vietnamese enterprises are facing fierce competition and pressure of economic integration. The dynamic, potential but challenging business environment requires Vietnamese enterprises to apply a management accounting system with suitable techniques in order to manage resources effectively and enhance competitive advantages.

\subsection{Enterprise size}

The research results show that the enterprise size has a positive impact on management accounting application with a coefficient of 0.210 . This indicates the larger the enterprise size (reflected by annual turnover, the number of employees, amount of capital, the number of products), the higher the use of management accounting. This result confirms hypothesis $\mathrm{H}_{1}$, and is consistent with previous studies of Kordlouie and Hosseinpour (2018), Afirah (2018), Armitage and Webb (2013). In Vietnam, when it comes to enterprise size, there is a big difference between small enterprises, medium-sized enterprises and large enterprises regarding the application of management accounting. Specifically, large-scale enterprises with strong financial capacity, diverse products, and large market share, with complex management systems require highly sophisticated management accounting techniques. In small enterprises, it is not necessary to design a management accounting system. However, it is possible to apply management accounting in small companies especially at high level management. The owners/ managers of enterprises or the chief accountants must equip themselves with knowledge and application of management accounting. The application of management accounting in small businesses can help them reduce risks through budgeting tools, create better business plan or take advantages of business opportunities.

\subsection{Organizational culture}

In this study, the organizational culture has the highest impact on the application of management accounting in enterprises, with the coefficient of 0.375 . Research results show that support from managers to employees, consensus on development goals, and cooperation of employees in departments increase the feasibility of management accounting application. This result confirms hypothesis H6, and is consistent with previous studies of Erserim (2012), Chenhall (2007), XydiasLobo et al. (2004), Laitinen (2003). In Vietnam, the majority of enterprises are small enterprises with personal and family relationships. Therefore, the consistency and conformity are relatively high which can facilitate the application of management accounting such as developing standard costing; decision making tools; budgeting and control; performance measurement can reach high consensus from business departments, and the Board of Directors. 


\subsection{Organizational structure}

The results of regression analysis show that organizational structure has a positive effect on the application of management accounting in enterprises, with the coefficient of 0.269 . This factor has the highest impact on the dependent variable. This result confirms hypothesis $\mathrm{H} 4$ that, and is consistent with previous studies of Fasesin (2015), Lavia et al. (2015), Abdel and Luther (2008). Enterprises in Vietnam operate under the Vietnamese Enterprise Law and often have line and functional organizational structure. Specifically, clear structure of enterprises is reflected in the division of the organization into small units such as departments, units, teams with specific tasks, and performance of each unit is periodically evaluated. Therefore, clear organizational structure facilitates the application of management accounting in Vietnamese enterprises.

\subsection{Technology}

This study proved that technology has a positive impact on the application of management accounting (coefficient $=0.203$ ). This result confirms hypothesis $\mathrm{H}_{5}$, and is consistent with previous studies of Kordlouie and Hosseinpour (2018), Afirah (2018), Lavia et al. (2015), Ahmad (2012). In the era of industrial revolution 4.0, technology has a great influence on business activities. New technology allows high-level automation in producing and manufacturing as well as communication and cooperation between machines and humans in a real-time. Specifically, technology is represented by the degree of automation in the processes of production, sales, personnel, business, management. It enables rapid production and standardized quality. This study also showed that technology factors and firm size (the amount of capital and the number of product) have a positive impact on the application of management accounting. Hardware and software technologies are applied and enhance efficiency in foreign-invested companies (joint ventures). Companies with a capital of more than 200 billion VND, revenues of more than 200 billion VND, and more than 200 products such as Samsung, Toyota, Canon, apart from machinery and equipment, they also apply technology such as management process, automatic production, employee work trackers, controlling inventory, materials. The automation level may reach 52\%. In State-owned companies, technology is not advanced and includes mainly machinery and equipment with poor operation and management processes. The amount of investment in technology in the private sector (limited liability companies and joint stock companies) is smaller than that in stated-owned enterprises, but higher efficiency.

\subsection{Human resources management}

The factor of human resources management has a positive influence on the application of management accounting, however the level of impact is small (0.046). The management of human resources depends greatly on the perspectives and strategies of the managers. With highly flexible management strategy, companies need to apply complex management accounting techniques to collect relevant information for making decisions in diverse business contexts.

\section{Summary and Conclusion}

Management accounting is considered a component of management system in enterprises. Managers at all levels can use management accounting information to perform management functions and achieve business objectives. However, application of management accounting is affected by many factors, so investigating influential factors is essential. This study using quantitative research method proved that organizational culture has the highest impact of management accounting application, followed by organizational structure and technology. Therefore, potential solutions for enterprises are proposed as follows:

Solutions regarding organizational culture: Organizational culture is one of the most valuable assets of an organization which should be preserved and promoted by its members. Companies with strong cultures have a high consensus among members toward common objectives which is a critical factor for long-term success. Potential solutions for companies to promote and strengthen their culture include 
(i) Developing an investment strategy to explore and promote strengths and talents of each employee in the organization; (ii) Regularly evaluating strengths and weaknesses of corporate culture to communicate and remind responsibilities and obligations of each individual in enterprises; (iii) Organizing events to enhance teambuilding, contests, programs to enhance cooperation and help employees understand corporate culture as well as the importance and benefits of the development of the enterprises and its members.

Solutions regarding enterprise size: There are many different ways to increase enterprise size such as mergers, integrations, alliances. With larger size, companies can have sufficient financial capacity to access capital from banks. It is recommendable to diversify business activities, products. Furthermore, in order to apply management accounting effectively, appropriate data collection should be emphasized which allows better processing of data and making reports for managers at all levels. In other words, it is critical to maintain high consistency from data collection to data analysis

Solutions regarding business environment: Business environment is an external factor which has a negative impact on the application of management accounting in Vietnamese enterprises. Since it is impossible to restrain or reduce the impact of external environment, an effective solution is to adapt to the environment and take control of enterprises' production and business activities. Particularly, enterprises should select appropriate management accounting techniques to help managers make right decisions to tackle environmental instability.

Solutions regarding organizational structures: Enterprises should select suitable management structures, adapt the management structures in relation to organizational cultures. Furthermore, management structures should be established based on responsibility center.

\section{References}

Abdel-Kader, M., \& Luther, R. (2006). Management accounting practices in the British food and drinks industry. British Food Journal, 108(5), 336-357.

Abdel-Kader, M., \& Luther, R. (2008). The impact of firm characteristics on management accounting practices: A UK-based empirical analysis. The British Accounting Review, 40(1), 2-27.

Abdel-Maksoud, A. B. (2004). Manufacturing in the UK: contemporary characteristics and performance indicators. Journal of Manufacturing Technology Management, 15(2), 155-171.

Azudin, A., \& Mansor, N. (2018). Management accounting practices of SMEs: The impact of organizational DNA, business potential and operational technology. Asia Pacific Management Review, 23(3), 222-226.

Ahmad, K. (2012). The use of management accounting practices in Malaysia SMEs. PhD thesis. University of Exeter.

Amat, J., Carmona, S., \& Chenhalls, H. (1994). Context and change in management accounting systems: a Spanish case study. Management Accounting Research, 5(2), 107-122.

Armitage, H. M., \& Webb, A. (2013). The Use of Management Accounting Techniques by Canadian Small and Medium Sized Enterprises: A Field Study. In CAAA Annual Conference.

Atkinson, A. (2012). Management accounting: information for decision-making and strategy executive. $6^{\text {th }}$ ed., Pearson Prentice Hall.

Bhimani, A. (2002). Management Accounting and Organizational Excellence. Management Press International LTD, United Kingdom.

Birkett, W. P., Barbera, M. R., Chua, W. F., Fatseas, V. A., Luckett, P. F., \& Macmullen, J. S. (1992). Cost management in small manufacturing enterprises. Australian Centre for Management Accounting Development, UNSW, Sydney.

Chenhall, R. H. (2006). Theorizing contingencies in management control systems research. Handbooks of Management Accounting Research, 1, 163-205.

Collis, J., \& Jarvis, R. (2002). Financial information and the management of small private companies. Journal of Small Business and Enterprise Development, 9(2), 100-110.

Dehejia, R. H., \& Wahba, S. (2002). Propensity score-matching methods for nonexperimental causal studies. Review of Economics and statistics, 84(1), 151-161.

Erserim, A. (2012). and external environment of firms on management accounting practices: an empirical research on industrial firms in Turkey. Procedia-Social and Behavioral Sciences, 62, 372-376.

Fasesin, O. O., Salman, A. Y., \& Dunsin, A. T. (2015). Influence of management accounting system on 
performance of small and medium enterprises in Nigeria. International Journal in Management and Social Science, 3(4), 435-446.

Hair, J. F. J., Anderson, R. E., Tatham, R. L.,\& Black, W. C. (1998). Multivariate Date Analysis. New Jersey: Prentice Hall.

Kordlouie, H. R., \& Hosseinpour, A. (2018). Management accounting practices in small and medium-sized enterprises regarding the impact of organizational and, commercial potential and operational technology, International Journal of Business quantitative economic and applied management research, 4(8), January2018

Hiebl, M. R., Feldbauer-Durstmüller, B., \& Duller, C. (2013). The changing role of management accounting in the transition from a family business to a non-family business. Journal of Accounting \& Organizational Change, 9(2), 119-154.

Hung, N. T. (2016). Factors affecting management accounting application in small and medium-sized enterprises in Vietnam. Ph.D thesis, University of Economics, Ho Chi Minh City.

Hyvönen, J. (2007). Strategy, performance measurement techniques and information technology of the firm and their links to organizational performance. Management Accounting Research, 18(3), 343-366.

Kaplan, R., \& Atkinson, A. (1998). Advanced Management Accounting. 3rd edition. USA, Hall Inc. Prentice International.

Kosaiyakanont A. (2011). SME Entrepreneurs in Northern Thailand: Their Perception of and Need for Management Accounting. Journal of Business and Policy Research, 6, 143-155.

Laitinen, E. K. (2003). Future-based management accounting: a new approach with survey evidence. Critical Perspectives on Accounting, 14(3), 293-323.

Langfield-Smith, K., Smith, D., Andon, P., Hilton, R., \& Thorne, H. (2017). Management accounting: Information for creating and managing value. McGraw-Hill Education Australia.

Lavia L opez, O., \& Hiebl, M. R. W. (2015). Management accounting in small and medium-sized enterprises e current knowledge and avenues for further research. Journal of Management Accounting Research, 27(1), 81-119.

Messner, M. (2016). Does industry matter? How industry context shapes management accounting practice. Management Accounting Research, 31, 103-111.

Michael, L., Malcolm, P. and Glynn, L. (2013). Management Accounting Practices of (UK) Small - Medium Sized Enterprises. Improving SME performance through Management Accounting Education. CIMA. 9:4.

Mitchell, F., \& Reid, G. C. (2000). Problems, challenges and opportunities: the small business as a setting for management accounting research. Management Accounting Research, 11(4), 385-390.

Nandan, R. (2010). Management Accounting Needs of SMEs and the Role of Professional Accountants: A Renewed Research Agenda. Journal of applied management accounting research, 8(1).

Nishimura, A. (2003). Management Accounting: Feed forward and Asian perspectives. New York, NY: Palgrave Macmillan.

Pierce, B., \& O'Dea, T. (1998). Management accounting practices in Ireland-the preparers' perspective.

Scarbrough, P., Nanni Jr, A. J., \& Sakurai, M. (1991). Japanese management accounting practices and the effects of assembly and process automation. Management Accounting Research, 2(1), 27-46.

Senftlechner, D., \& Hiebl, M. R. (2015). Management accounting and management control in family businesses: Past accomplishments and future opportunities. Journal of Accounting \& Organizational Change, 11(4), 573606.

Shields, M. D. (1997). Research in management accounting by North Americans in the 1990s. Journal of management accounting research, 9, 3-62.

Valančienè, L., \& Gimžauskienė, E. (2007). Changing role of management accounting: Lithuanian Experience case studies. Inžinerine ekonomika, (5), 16-23.

Yen, T. T. (2017). Factors affecting management accounting application in small and medium-sized enterprises in Binh Dinh province. Industry and Trade Magazine. <http://www.tapchicongthuong.vn/bai-viet/nhan-toanh-huong-den-viec-van-dung-ke-toan-quan-tri-trong-cac-doanh-nghiep-tai-tinh-binh-dinh-27201.htm>

Xydias-Lobo, M., Tilt, C., \& Forsaith, D. (2004). The future of management accounting: a South Australian perspective. Journal of Applied Management Accounting Research, 2(1), 55.

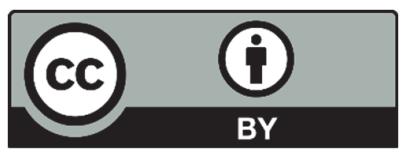

(C) 2020 by the authors; licensee Growing Science, Canada. This is an open access article distributed under the terms and conditions of the Creative Commons Attribution (CC-BY) license (http://creativecommons.org/licenses/by/4.0/). 